\title{
Nanotherapy and Reactive Oxygen Species (ROS) in Cancer: A Novel Perspective
}

\author{
Peter Brenneisen * and Andreas S. Reichert \\ Institute of Biochemistry and Molecular Biology I, Medical Faculty, Heinrich-Heine-University Düsseldorf, \\ 40225 Düsseldorf, Germany; reichert@hhu.de \\ * Correspondence: peter.brenneisen@hhu.de; Tel.: +49-211-81-12715
}

Received: 23 January 2018; Accepted: 19 February 2018; Published: 22 February 2018

\begin{abstract}
The incidence of numerous types of cancer has been increasing over recent years, representing the second-most frequent cause of death after cardiovascular diseases. Even though, the number of effective anticancer drugs is increasing as well, a large number of patients suffer from severe side effects (e.g., cardiomyopathies) caused by these drugs. This adversely affects the patients' well-being and quality of life. On the molecular level, tumor cells that survive treatment modalities can become chemotherapy-resistant. In addition, adverse impacts on normal (healthy, stromal) cells occur concomitantly. Strategies that minimize these negative impacts on normal cells and which at the same time target tumor cells efficiently are needed. Recent studies suggest that redox-based combinational nanotherapies may represent one option in this direction. Here, we discuss recent advances in the application of nanoparticles, alone or in combination with other drugs, as a promising anticancer tool. Such novel strategies could well minimize harmful side effects and improve patients' health prognoses.
\end{abstract}

Keywords: tumor-stroma interaction; reactive oxygen species (ROS); chemotherapeutics; nanoparticle; cerium oxide; mitochondria; combinational therapy

\section{Redox-Based Combinational Nanotherapy: A Novel Anticancer Strategy}

Numerous approaches in anticancer therapy focus largely on tumor cells, and solely address the question of how anticancer drugs affect tumor cell survival and metastasis [1-4]. The bilateral communication between cancer cells and the tumor microenvironment-the so-called tumor-stroma interaction-is usually neglected [5-7]. There is increasing evidence that stromal components actively take part, for example, in tumor invasion, neoangiogenesis, metastasis, and development of drug resistance [8,9]. Aside from components of the extracellular matrix and soluble factors, cellular components such as immune cells, endothelial cells, and cancer-associated fibroblast are involved in the interplay with tumor cells [10]. In the battle against cancer, traditional options such as surgery, radiation therapy and/or chemotherapy are used, but often result in harmful side effects on normal (healthy, stromal) cells, thus affecting the whole organism and carrying the risk of late secondary cancer.

Many of the well-used "classical" chemotherapeutic agents show a very effective cytostatic/cytotoxic function based on their broad range of chemical efficacy. Examples include cisplatin or anthracyclin derivates such as doxorubicin (adriamycin) or daunorubicin [11], among others. In fact, those drugs act rather unspecifically, and thus they adversely influence healthy/stromal cells and tissues. Alopecia, vomiting, nausea, mucositis, cardiomyopathies, and nephrotoxicity are some of the severe side effects to the patients to name but a few. Furthermore, the occurrence of drug resistance and prevention of overcoming the blood-brain barrier (BBB) can be problematic with these drugs as well [12-16]. Owing to this detrimental impact of those chemotherapeutics on mental and physical well-being and quality of life for cancer patients, it is mandatory in the near future to develop novel and/or supplemental or 
combinational therapies which, on the one hand, lower harmful effects; and on the other hand, improve lifespan and quality of life of the patients. In that context, a personalized medicine may be of advantage, meaning specific drugs, inhibitors and antibodies among others used for treatment tailored to a single patient's genetic profile. But on the other hand, the improved health outcome for such patients may only come at a high cost for the patient and/or for the health insurance companies, as it is presently still very costly to screen patients for such specialized treatments and to produce medicine that targets only individuals or narrow groups of patients. Even though most analytical studies describe many personalized medicine tests as being very cost-intensive, a few studies have found that a personalized medicine may save costs [17-20]. In conclusion, more evidence on the value of such a novel medicine is needed in the context of assessing genomic priorities, cost recovery and ethical aspects such as its availability for all groups of a population. But before such a personalized medicine can become a daily routine for all, possibly resulting in a "transparent man", another option in anticancer therapy may be able to modify already existing therapeutic approaches and combine them in novel combinational therapies, allowing (i) a direct transit of drugs to the tumor location; (ii) the killing of the tumor cells; and (iii) the protection of healthy/stromal cells against the dominating influence of the tumor cells on the stromal cells and against the damaging effect of the anticancer drug. Ultimately, this would result in fewer side effects and a better prognosis. Before discussing such a promising combinational approach, it is important to ask the question: "What is the difference between a tumor cell and its normal counterpart or stromal cell?" Aside from altered signaling pathways and metabolic processes, which differ from tumor type to tumor type, an increased level of reactive oxygen species (ROS) compared to normal cells is common to almost all tumor cells [21-23]. This is proposed as a possible common target for therapeutic approaches [24-26].

Depending on their reactivity and localization, ROS are involved in physiological (termed oxidative eustress) and pathophysiological processes (termed oxidative stress) $[27,28]$. One major source of increased cellular ROS levels is dysfunctional mitochondria [29]. However, increased ROS levels and, in consequence, an altered redox status of the cell provide a specific vulnerability of cancer cells, which can be used for therapeutic approaches [30]. Recently, two opposing redox status modulating therapies have been tested in clinical trials. In the first approach, antioxidants are used to lower the content of ROS in tumor cells, subsequently inducing cell cycle arrest and, lastly, apoptosis [31,32]. The other prooxidative concept aims to increase the ROS level of cancer cells to an extent that exceeds their survival strategies, and in the end results in an increased apoptotic rate as well $[24,26,33]$. Normally, the imbalance of the prooxidative and antioxidative systems towards higher ROS levels in cancer cells is still maintained below a cytotoxic threshold. Impairment of the cellular antioxidant system or treatment with exogenous ROS generating agents [11] might exceed a certain ROS threshold, thus resulting in detrimental oxidative stress. That stress can apparently not be compensated by the defense systems of cancer cells, finally leading to cytotoxic effects and lastly to apoptosis or necrosis. In contrast, healthy cells are often able to counteract increased ROS levels by their endogenous antioxidant systems [34]. In addition to their cytostatic effects on tumor cells, chemotherapeutical drugs, such as the above-mentioned anthracyclins, may act as such prooxidants. Nevertheless, both tumor and normal (healthy, stromal) cells are damaged by such compounds, resulting in severe side effects. This is often accompanied by enhanced drug-mediated ABC- (ATP-binding cassette) expression in some tumor types $[35,36]$. Also a doxorubicin induced increase of autophagy associated with an increase in survival and a lowered apoptosis rate was observed [37,38], which may result in increased tumor resistance. Therefore, the clinical use and outcome of these "dirty drugs" seems to be limited in terms of application [39]. But what can be done? Recently, molecules acting on ROS production, disrupting mitochondrial function and, finally, resulting in apoptosis of cancer cells are discussed. In that context, manganese (Mn)-superoxide dismutase (SOD) mimics [40], copper(II) phenanthroline metallopeptides [41], selenium-containing quinone-based triazoles [42] or organoiridium complexes [43] are some examples of molecules/catalysts being promising anticancer agents. In nanotherapy, the medical application of nanotechnology, promising approaches are currently 
developed and partly already tested in clinical trials [44]. One of the promising applications in nanomedicine is the use of nanoparticles $(<100 \mathrm{~nm}$ in size) as carrier system for drug delivery to specific cellular targets or organs, for example the transport to mitochondria [45] or to the brain [46]. Here are just four of the many examples that could be mentioned, bringing to mind the tremendous potential of nanocarriers in anticancer therapies. In an interesting approach using a rat glioma model, the acidic tumor microenvironment was exploited to transport $\mathrm{pH}$-sensitive doxorubicin-loaded PEGylated-gold nanoparticles to the tumor site, resulting in rapid release of doxorubicin at low $\mathrm{pH}$ and in an increase of ROS level [47]. Recently, doxorubicin-loaded lipid nanoparticles were tested for topical treatment of skin cancer. Cytotoxicity data with murine melanoma cells and the histological analysis of melanoma induced Balb/C mice showed promising results with those nanoparticles [48]. Furthermore, encapsulation of the platinum(IV) prodrug mitaplatin in block copolymer nanoparticles resulted in an increase in drug circulation time in blood and in a controlled drug release [49]. Due to their nontoxic nature, carbon-based nanoparticles (carbon dots, carbon nanotubes) are used as platform to deliver drugs such as doxorubicin and gemcitabine to the tumor site [50]. However, most of these nanoparticles still face tremendous challenges regarding their limited biocompatibility and subsequent low cytotoxicity in some types of tumor cells [45,51]. Meanwhile, the application of nanoparticles, which themselves act directly as pharmacological substances (nanopharmaceutical), appears to be another therapeutic possibility for the treatment of some cancer types. In this context, especially the lanthanide cerium in the form of polymer-coated or polyacrylate-stabilized cerium oxide $\left(\mathrm{CeO}_{2} / \mathrm{Ce}_{2} \mathrm{O}_{3}\right)$ nanoparticles ( $\mathrm{CNP}$, nanoceria), shows promising properties regarding a redox-modulatory and enzyme-like activity. Due to oxygen vacancies on the surface of CNP and the ability to autocatalytically switch between the oxidation states IV $\left(\mathrm{Ce}^{4+}\right)$ and III $\left(\mathrm{Ce}^{3+}\right), \mathrm{CNP}$ function as a pro- or antioxidant based on the microenvironment [52-55]. Such nanopharmaceuticals can be used in a redox-based chemotherapy as "stand-alone drugs", or in combination with classical chemotherapeutical agents, like the successful approaches with doxorubicin (see below). In recent years, an increasing number of articles have dealt with nanoceria as an antioxidant-detoxifying superoxide, hydrogen peroxide, and peroxynitrite and, therefore, as having a beneficial effect on different cells and tissues in vitro [56-60]. For example, CNP protect human dermal fibroblasts from the redox cycler paraquat (PQ) initiated increase of superoxide $\left(\mathrm{O}_{2}{ }^{-}\right)$level [56]. The uptake of nanoceria results in a subcellular distribution (Figure 1). Interestingly, it seems that CNP do not enter the nucleus and, thus, exert no genotoxicity which is beneficial for normal, healthy cells [11]. On the other hand, CNP were shown by others to be present in the nucleus and, notably, also to be co-localized with ROS-producing mitochondria [61].

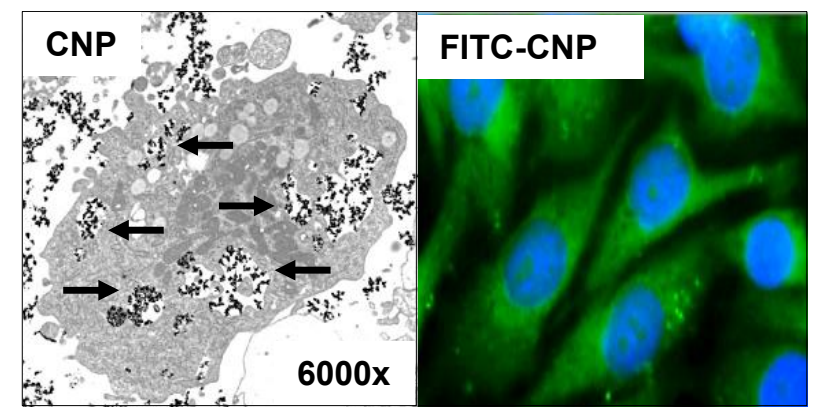

Figure 1. Cellular uptake of cerium oxide nanoparticles (CNP) Squamous tumor cells of the skin were treated with $150 \mu \mathrm{M}$ CNP or fluorescein isothiocyanate (FITC)-labeled CNP for $24 \mathrm{~h}$. Data of studies with trans electron microscopy (left) indicate uptake of CNP (see arrows). Studies with FITC-CNP (green fluorescence) show distribution of CNP in the cytosol, while there appears no green fluorescence (or merged cyan fluorescence) of the nuclei (blue, $4^{\prime}$,6-Diamidin-2-phenylindol (DAPI)-staining).

Hirst and coworker detected CNP around the mitochondria which subsequently scavenge mitochondria-generated ROS in normal murine macrophages [62]. Furthermore, nanoceria were shown 
to protect mitochondria from mitochondrial fragmentation (fission) in primary skin fibroblasts [63]. Nanoceria caused an increased release of cytochrome $c$ from mitochondria into the cytosol in tumor cells [64]. Overall, CNP appear to act inter alia via modulating mitochondrial function and/or mitochondrial ROS generation. In skin cancer and glioma cells, exogenously added CNP with a defined size have been shown to act as a cell-killing and anti-invasive agent via increasing the level of distinct reactive oxygen species like hydrogen peroxide. In contrast, the same concentration of CNP is nontoxic in stromal (healthy) fibroblasts or endothelial cells [64-66], suggesting a bifunctional role of nanoceria in tumor-stroma (Scheme 1). In this context, in a combinational approach with the chemotherapeutical drug doxorubicin, CNP enhance the ROS-mediated toxicity of doxorubicin in different cancer cells, while CNP exhibit some protection against doxorubicin mediated cell death in human dermal fibroblasts and rat cardiomyocytes [11,67]. In addition to the increasing number of publications with in vitro data, more and more in vivo data are available today. To quote only three, the infiltration of immune cells and the expression of proinflammatory cytokines, which goes hand-in-hand with ventricular dysfunction and dilatation, can be significantly lowered by the use of cerium oxide nanoparticles, studied on a murine model of cardiomyopathy [68]. Our studies on a xenograft mouse model show that CNP significantly lower tumor growth and invasion and, furthermore, inhibit some processes of neoangiogenesis [64]. Recently, folic acid-tagged cerium oxide nanoparticles have been shown to increase the cellular nanoparticle internalization and inhibit cell proliferation of an ovarian cancer cell line and significantly lower the tumor burden of such mouse xenografts [69]. Aside from the use in cancer research, it was shown in animal models that mitochondria-targeted cerium oxide nanoparticles protect against amyloid beta $(\mathrm{A} \beta)$ induced mitochondrial fragmentation and cell death in a model for Alzheimer's disease [70,71].

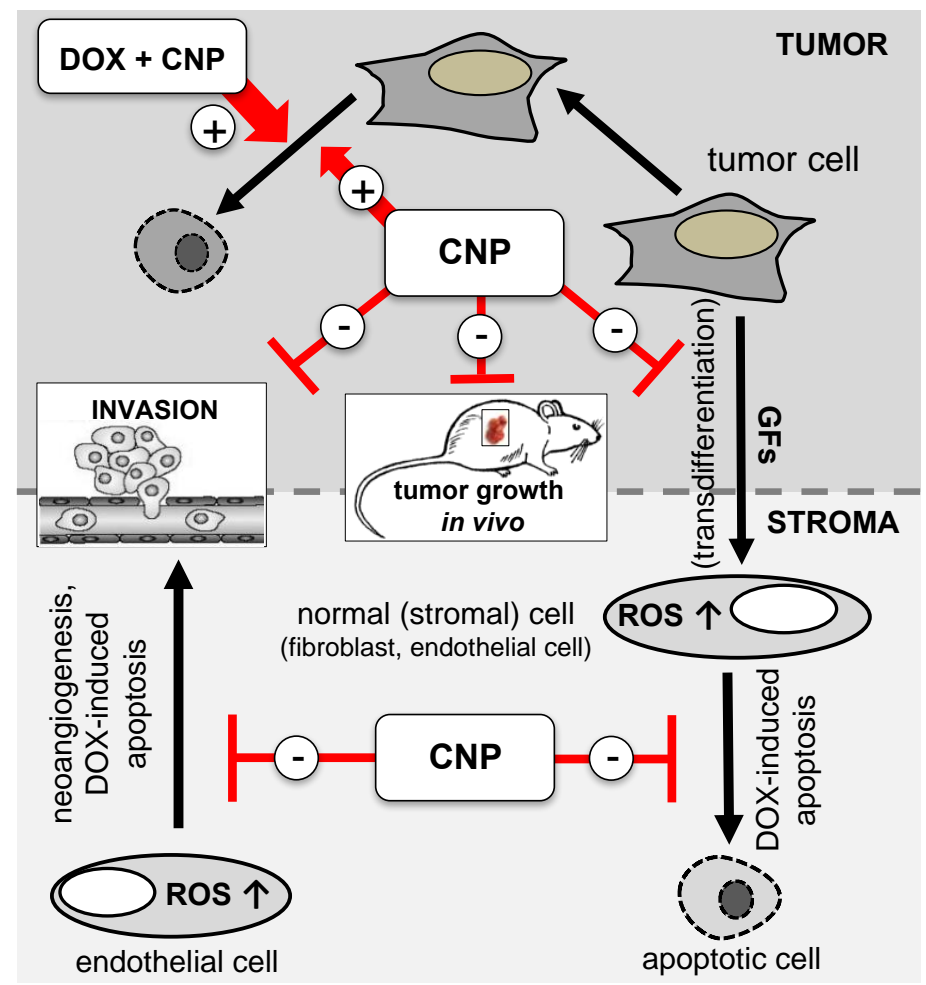

Scheme 1. Bifunctional role of cerium oxide nanoparticles (CNP) in tumor-stroma interaction CNP prevent (-) tumor cell-derived growth factor (GF)-dependent modulation of normal (stromal) cells (e.g., transdifferentation, neoangiogenesis) and mediate their protection from doxorubicin (DOX)-initiated apoptotic cell death. Furthermore, CNP lower tumor invasion and tumor growth in vivo. In contrast, CNP induce (+) reactive oxygen species (ROS)-mediated cell death in the studied tumor cells and enhance the apoptotic rate in a combinational approach with DOX $[11,58,60]$. 
Aside from the fact that a planned personalized (anticancer) medicine in the future still presents many questions and challenges, it appears that other possible anticancer strategies are already available, dealing with major challenges such as killing the tumor cells without damaging normal (healthy, stromal) cells, and lowering harmful effects to improve prognosis and quality of life of the patient. In particular, a ROS-modulating nanotherapy could play an important role in the 21st century. A nanoparticle-based anticancer therapy with either specific nanocarriers or nanopharmaceuticals, which have tremendous potential in a combination therapy, could support classical anticancer strategies such as the use of ROS-producing anthracyclins. Such a nanoparticle-based combination therapy could fulfill the above-mentioned anticancer guideline of killing tumor cells and leaving normal cells intact with less side effects. Certainly, other combinational anticancer approaches, which are independent of the use of nanoparticles, but also depend on modulation of the ROS level, will be discussed to be promising for an anticancer therapy [72].

\section{Conclusions}

In conclusion, special nanoparticles such as cerium oxide nanoparticles (nanoceria) appear to be a promising and powerful tool for the development of a nanoparticle-based redox-directed combinational anticancer therapy in the (near) future that is accessible to all classes of society. Such an approach may combine the high efficacy of chemotherapeutical drugs, such as the anthracyclines, with the drug supporting effect (on tumor cells) and protecting potential (on normal cells) of bifunctionally active nanoparticles. However, more data from animal models and current and future clinical trials will show whether the nanomedicine will meet the expectations generated by the recent promising results in cancer research as well as in other fields including neurodegeneration.

Author Contributions: Peter Brenneisen is working on ROS effects and the effect of redox-active nanoparticles in tumor-stroma interactions. He is mainly responsible for the idea and the content of that article. Andreas S. Reichert is working on mitochondrial morphology and mitochondrial dynamics in health and disease. He provided complementary aspects which strengthen the proposed opinion.

Conflicts of Interest: The authors declare no conflict of interest.

\section{References}

1. Atkinson, V. Medical management of malignant melanoma. Aust. Prescr. 2015, 38, 74-78. [CrossRef] [PubMed]

2. Rajanna, S.; Rastogi, I.; Wojdyla, L.; Furo, H.; Kulesza, A.; Lin, L.; Sheu, B.; Frankes, M.; Ivanovic, M.; Puri, N. Current Molecularly Targeting Therapies in NSCLC and Melanoma. Anticancer Agents Med. Chem. 2015, 15, 856-868. [CrossRef] [PubMed]

3. Langdon, S.P.; Cameron, D.A. Pertuzumab for the treatment of metastatic breast cancer. Expert Rev. Anticancer Ther. 2013, 13, 907-918. [CrossRef] [PubMed]

4. Flaherty, K.T. Sorafenib: Delivering a targeted drug to the right targets. Expert Rev. Anticancer Ther. 2007, 7, 617-626. [CrossRef] [PubMed]

5. De Vlieghere, E.; Verset, L.; Demetter, P.; Bracke, M.; De Wever, O. Cancer-associated fibroblasts as target and tool in cancer therapeutics and diagnostics. Virchows Arch. 2015, 467, 367-382. [CrossRef] [PubMed]

6. Fang, H.; Declerck, Y.A. Targeting the tumor microenvironment: From understanding pathways to effective clinical trials. Cancer Res. 2013, 73, 4965-4977. [CrossRef] [PubMed]

7. Cat, B.; Stuhlmann, D.; Steinbrenner, H.; Alili, L.; Holtkötter, O.; Sies, H.; Brenneisen, P. Enhancement of tumor invasion depends on transdifferentiation of skin fibroblasts mediated by reactive oxygen species. J. Cell Sci. 2006, 119, 2727-2738. [CrossRef] [PubMed]

8. Mei, L.; Du, W.; Ma, W.W. Targeting stromal microenvironment in pancreatic ductal adenocarcinoma: Controversies and promises. J. Gastrointest. Oncol. 2016, 7, 487-494. [CrossRef] [PubMed]

9. De Wever, O.; Demetter, P.; Mareel, M.; Bracke, M. Stromal myofibroblasts are drivers of invasive cancer growth. Int. J. Cancer 2008, 123, 2229-2238. [CrossRef] [PubMed]

10. Desmoulière, A.; Guyot, C.; Gabbiani, G. The stroma reaction myofibroblast: A key player in the control of tumor cell behavior. Int. J. Dev. Biol. 2004, 48, 509-517. [CrossRef] [PubMed] 
11. Sack, M.; Alili, L.; Karaman, E.; Das, S.; Gupta, A.; Seal, S.; Brenneisen, P. Combination of conventional chemotherapeutics with redox-active cerium oxide nanoparticles-A novel aspect in cancer therapy. Mol. Cancer Ther. 2014, 13, 1740-1749. [CrossRef] [PubMed]

12. Cappetta, D.; Rossi, F.; Piegari, E.; Quaini, F.; Berrino, L.; Urbanek, K.; De Angelis, A. Doxorubicin targets multiple players: A new view of an old problem. Pharmacol. Res. 2018, 127, 4-14. [CrossRef] [PubMed]

13. Manohar, S.; Leung, N. Cisplatin nephrotoxicity: A review of the literature. J. Nephrol. 2017. [CrossRef] [PubMed]

14. Edwardson, D.W.; Narendrula, R.; Chewchuk, S.; Mispel-Beyer, K.; Mapletoft, J.P.; Paissenti, A.M. Role of drug metabolism in the cytotoxicity and clinical efficacy of anthracyclines. Curr. Drug Metab. 2015, 16, 412-426. [CrossRef] [PubMed]

15. Drapeau, A.; Fortin, D. Chemotherapy delivery strategies to the central nervous system: Neither optional nor superfluous. Curr. Cancer Drug Targets 2015, 15, 752-768. [CrossRef] [PubMed]

16. Ingawale, D.K.; Mandlik, S.K.; Naik, S.R. Models of hepatotoxicity and the underlying cellular, biochemical and immunological mechanism(s): A critical discussion. Environ. Toxicol. Pharmacol. 2014, 37, 118-133. [CrossRef] [PubMed]

17. Alaba, H.; Lim, C.; Leighl, N.B. Economic considerations in the use of novel targeted therapies for lung cancer: Review of current literature. Pharmacoeconomics 2017, 35, 1195-1209. [CrossRef] [PubMed]

18. Hörster, L.; Schlenk, R.F.; Stadler, M.; Gabriel, M.; Thol, F.; Schildmann, J.; Vollmann, J.; Rochau, U.; Sroczynski, G.; Wasem, J.; et al. Cost-effectiveness of methods in personalized medicine. Results of a decision-analytic model in patients with acute myeloid leukemia with normal karyotype. Leuk. Res. 2017, 62, 84-90. [CrossRef] [PubMed]

19. Phillips, K.A.; Sakowski, J.A.; Trosman, J.; Douglas, M.P.; Liang, S.Y.; Neumann, P. The economic value of personalized medicine tests: What we know and what we need to know. Genet. Med. 2014, 16, 251-257. [CrossRef] [PubMed]

20. Fleck, L.M. Just caring: Assessing the ethical and economic costs of personalized medicine. Urol. Oncol. 2014, 32, 202-206. [CrossRef] [PubMed]

21. Rodic, S.; Vincent, M.D. Reactive oxygen species (ROS) are a key determinant of cancer's metabolic phenotype. Int. J. Cancer 2018, 142, 440-448. [CrossRef] [PubMed]

22. Panieri, E.; Santoro, M.M. ROS homeostasis and metabolism: A dangerous liason in cancer cells. Cell Death Dis. 2016, 7, e2253. [CrossRef] [PubMed]

23. Cerutti, P.A. Prooxidant states and tumor promotion. Science 1985, 227, 2085-2087. [CrossRef]

24. Raza, M.H.; Siraj, S.; Arshad, A.; Waheed, U.; Aldakheel, F.; Alduraywish, S.; Arshad, M. ROS-modulated therapeutic approaches in cancer treatment. J. Cancer Res. Clin. Oncol. 2017, 143, 1789-1809. [CrossRef] [PubMed]

25. Zhang, L.; Li, J.; Zong, L.; Chen, X.; Chen, K.; Jiang, Z.; Nan, L.; Li, X.; Li, W.; Shan, T.; et al. Reactive oxygen species and targeted therapy for pancreatic cancer. Oxid. Med. Cell. Longev. 2016. [CrossRef] [PubMed]

26. Liu, J.; Wang, Z. Increased oxidative stress a selective anticancer therapy. Oxid. Med. Cell. Longev. 2015, $2015,294303$. [CrossRef] [PubMed]

27. Sies, H.; Berndt, C.; Jones, D.P. Oxidative stress. Annu. Rev. Biochem. 2017, 86, 715-748. [CrossRef] [PubMed]

28. Sies, H. Oxidative stress: A concept in redox biology and medicine. Redox Biol. 2015, 4, 180-183. [CrossRef] [PubMed]

29. Droese, S.; Brandt, U. Molecular mechanisms of superoxide production by the mitochondrial respiratory chain. Adv. Exp. Med. Biol. 2012, 748, 145-169.

30. Cui, X. Reactive oxygen species: The achilles' heel of cancer cells? Antioxid. Redox Signal. 2012, 16, 1212-1214. [CrossRef] [PubMed]

31. Sznarkowska, A.; Kostecka, A.; Meller, K.; Bielawski, K.P. Inhibition of cancer antioxidant defense by natural compounds. Oncotarget 2017, 8, 15996-16016. [CrossRef] [PubMed]

32. Prasad, S.; Gupta, S.C.; Tyagi, A.K. Reactive oxygen specis (ROS) and cancer: Role of antioxidative nutraceuticals. Cancer Lett. 2017, 387, 95-105. [CrossRef] [PubMed]

33. Gupta, S.C.; Hevia, D.; Patchva, S.; Park, B.; Koh, W.; Aggarwal, B.B. Upsides and downsides of reactive oxygen species for cancer: The roles of reactive oxygen species in tumorigenesis, prevention, and therapy. Antioxid. Redox Signal. 2012, 16, 1295-1322. [CrossRef] [PubMed]

34. Gorrini, C.; Harris, I.S.; Mak, T.W. Modulation of oxidative stress as an anticancer strategy. Nat. Rev. Drug Discov. 2013, 12, 931-947. [CrossRef] [PubMed] 
35. Liesa, M.; Qiu, W.; Shirihai, O.S. Mitochondrial ABC transporters function: The role of ABCB10 (ABC-me) as a novel player in cellular handling of reactive oxygen species. Biochim. Biophys. Acta 2012, 1823, 1945-1957. [CrossRef] [PubMed]

36. Elliott, A.M.; Al-Hajj, M.A. ABCB8 mediates doxorubicin resistance in melanoma cells by protecting the mitochondrial genome. Mol. Cancer Res. 2009, 7, 79-87. [CrossRef] [PubMed]

37. Wang, L.; Zhang, H.; Sun, M.; Yin, Z.; Qian, J. High mobility group box 1-mediated autophagy promotes neuroblastoma cell chemoresistance. Oncol. Rep. 2015, 34, 2969-2976. [CrossRef] [PubMed]

38. Tan, Q.; Wang, H.; Hu, Y.; Hu, M.; Li, X.; Ma, Y.; Wei, C.; Song, L. Src/STAT3-dependent heme oxygenase-1 induction mediates chemoresistance of breast cancer cells to doxorubicin by promoting autophagy. Cancer Sci. 2015, 106, 1023-1032. [CrossRef] [PubMed]

39. Berthiaume, J.M.; Wallace, K.B. Adriamycin-induced oxidative mitochondrial cardiotoxicity. Cell Biol. Toxicol. 2007, 23, 15-25. [CrossRef] [PubMed]

40. Nicco, C.; Batteux, F. ROS modulator molecules with therapeutic potential in cancers treatments. Molecules 2018, 23, 84. [CrossRef] [PubMed]

41. Laws, K.; Bineva-Todd, G.; Eskandari, A.; Lu, C.; O’Reilly, N.; Suntharalingam, K. A copper(II) phenanthroline metallopeptide that targets and disrupts mitochondrial function in breast cancer stem cells. Angew. Chem. Int. Ed. Engl. 2018, 57, 287-291. [CrossRef] [PubMed]

42. Jardim, G.A.M.; da Cruz, E.H.G.; Valenca, W.O.; Lima, D.J.B.; Cavalcanti, B.C.; Pessoa, C.; Rafique, J.; Braga, A.L.; Jacob, C.; da Silva Junior, E.N. Synthesis of selenium-quinone hybrid compounds with potential antitumor activity via Rh-catalyzed C-H bond activation and click reactions. Molecules 2018, 23, 83. [CrossRef] [PubMed]

43. Liu, Z.; Sadler, P.J. Organoiridium complexes: Anticancer agents and catalysts. Acc. Chem. Res. 2014, 47, 1174-1185. [CrossRef] [PubMed]

44. Schroeder, A.; Heller, D.A.; Winslow, M.M.; Dahlman, J.E.; Pratt, G.W.; Langer, R.; Jacks, T.; Anderson, D.G. Treating metastatic cancer with nanotechnology. Nat. Rev. Cancer 2011, 12, 39-50. [CrossRef] [PubMed]

45. Pathak, R.K.; Kolishetti, N.; Dhar, S. Targeted nanoparticles in mitochondrial medicine. Wiley Interdiscip. Rev. Nanomed. Nanobiotechnol. 2015, 7, 315-329. [CrossRef] [PubMed]

46. Pinto, M.P.; Arce, M.; Yameen, B.; Vilos, C. Targeted brain delivery nanoparticles for malignant gliomas. Nanomedicine 2017, 12, 59-72. [CrossRef] [PubMed]

47. Cheng, Y.; Dai, Q.; Morshed, R.A.; Fan, X.; Wegscheid, M.L.; Wainwright, D.A.; Han, Y.; Zhang, L.; Auffinger, B.; Tobias, A.L.; et al. Blood-brain barrier permeable gold nanoparticles: An efficient delivery platform for enhanced malignant glioma therapy imaging. Small 2014, 10, 5137-5150. [CrossRef] [PubMed]

48. Tupal, A.; Sabzichi, M.; Ramezani, F.; Kouhsoltani, M.; Hamishehkar, H. Dermal delivery of doxorubicin-loaded solid lipid nanoparticles for the treatment of skin cancer. J. Microencapsul. 2016, 33, 372-380. [CrossRef] [PubMed]

49. Barry, N.P.; Sadler, P.J. Challenges for metals in medicine: How nanotechnology may help to shape the future. ACS Nano 2013, 7, 5654-5659. [CrossRef] [PubMed]

50. Pardo, J.; Peng, Z.; Leblanc, R.M. Cancer targeting and drug delivery using carbon-based quantum dots and nanotubes. Molecules 2018, 23, 378. [CrossRef] [PubMed]

51. Kodiha, M.; Wang, Y.M.; Hutter, E.; Maysinger, D.; Stochaj, U. Off to the organelles-killing cancer cells with targeted gold nanoparticles. Theranostics 2015, 5, 357-370. [CrossRef] [PubMed]

52. Singh, S. Cerium oxide based nanozymes: Redox phenomenon at biointerfaces. Biointerphases 2016, 11, $04 \mathrm{~B} 202$. [CrossRef] [PubMed]

53. Pesic, M.; Podolski-Renic, A.; Stojkovic, S.; Matovic, B.; Zmejkoski, D.; Kojic, V.; Bogdanovic, G.; Pavicevic, A.; Mojovic, M.; Savic, A.; et al. Anti-cancer effects of cerium oxide nanoparticles and its intracellular redox activity. Chem. Biol. Interact. 2015, 232, 85-93. [CrossRef] [PubMed]

54. Das, S.; Dowding, J.M.; Klump, K.E.; McGinnis, J.F.; Self, W.T.; Seal, S. Cerium oxide nanoparticles: Applications and prospects in nanomedicine. Nanomedicine 2013, 8, 483-508. [CrossRef] [PubMed]

55. Karakoti, A.; Singh, S.; Dowding, J.M.; Seal, S.; Self, W.T. Redox-active radical scavenging nanomaterials. Chem. Soc. Rev. 2010, 39, 4422-4432. [CrossRef] [PubMed]

56. von Montfort, C.; Alili, L.; Teuber-Hanselmann, S.; Das, S.; Seal, S.; Brenneisen, P. Redox-active cerium oxide nanoparticles protect human dermal fibroblasts from PQ-induced damage. Redox Biol. 2015, 4, 1-5. [CrossRef] [PubMed] 
57. Walkey, C.; Das, S.; Seal, S.; Erlichman, J.; Heckman, K.; Ghibelli, L.; Traversa, E.; McGinnis, J.F.; Self, W.T. Catalytic Properties and Biomedical Applications of Cerium Oxide Nanoparticles. Environ. Sci. Nano 2015, 2, 33-53. [CrossRef] [PubMed]

58. Dowding, J.M.; Seal, S.; Self, W.T. Cerium oxide nanoparticles accelerate the decay of peroxynitrite (ONOO). Drug Deliv. Transl. Res. 2013, 3, 375-379. [CrossRef] [PubMed]

59. Pirmohamed, T.; Dowding, J.M.; Singh, S.; Wasserman, B.; Heckert, E.; Karakoti, A.S.; King, J.E.; Seal, S.; Self, W.T. Nanoceria exhibit redox state-dependent catalase mimetic activity. Chem. Commun. 2010, 46, 2736-2738. [CrossRef] [PubMed]

60. Heckert, E.G.; Karakoti, A.S.; Seal, S.; Self, W.T. The role of cerium redox state in the SOD mimetic activity of nanoceria. Biomaterials 2008, 29, 2705-2709. [CrossRef] [PubMed]

61. Singh, S.; Kumar, A.; Karakoti, A.S.; Seal, S.; Self, W.T. Unveiling the mechanism of uptake and sub-cellular distribution of cerium oxide nanoparticles. Mol. BioSyst. 2010, 6, 1813-1820. [CrossRef] [PubMed]

62. Hirst, S.M.; Karakoti, A.S.; Tyler, R.D.; Sriranganathan, N.; Seal, S.; Reilly, C.M. Anti-inflammatory properties of cerium oxide nanoparticles. Small 2009, 5, 2848-2856. [CrossRef] [PubMed]

63. Pezzini, I.; Marino, A.; Del Turco, S.; Nesti, C.; Doccini, S.; Cappello, V.; Gemmi, M.; Parlanti, P.; Santorelli, F.M.; Mattoli, V.; et al. Cerium oxide nanoparticles: The regenerative redox machine in bioenergetics imbalance. Nanomedicine 2017, 12, 403-416. [CrossRef] [PubMed]

64. Alili, L.; Sack, M.; von Montfort, C.; Giri, S.; Das, S.; Carroll, K.S.; Zanger, K.; Seal, S.; Brenneisen, P. Downregulation of tumor growth and invasion by redox-active nanoparticles. Antioxid. Redox Signal. 2013, 19, 765-778. [CrossRef] [PubMed]

65. Sack-Zschauer, M.; Bader, S.; Brenneisen, P. Cerium oxide nanoparticles as novel tool in glioma treatment: An in vitro study. J. Nanomed. Nanotechnol. 2017, 8, 474.

66. Alili, L.; Sack, M.; Karakoti, A.S.; Teuber, S.; Puschmann, K.; Hirst, S.M.; Reilly, C.M.; Zanger, K.; Stahl, W.; Das, S.; et al. Combined cytotoxic and anti-invasive properties of redox-active nanoparticles in tumor-stroma interactions. Biomaterials 2011, 32, 2918-2929. [CrossRef] [PubMed]

67. Sulthana, S.; Banerjee, T.; Kallu, J.; Vuppala, S.R.; Heckert, B.; Naz, S.; Shelby, T.; Yambem, O.; Santra, S. Combination therapy of NSCLC using Hsp90 inhibitor and doxorubicin carrying functional nanoceria. Mol. Pharm. 2017, 14, 875-884. [CrossRef] [PubMed]

68. Niu, J.; Azfer, A.; Rogers, L.M.; Wang, X.; Kolattukudy, P.E. Cardioprotective effects of cerium oxide nanoparticles in a transgenic murine model of cardiomyopathy. Cardiovasc. Res. 2007, 73, 549-559. [CrossRef] [PubMed]

69. Hijaz, M.; Das, S.; Mert, I.; Gupta, A.; Al-Wahab, Z.; Tebbe, C.; Dar, S.; Chhina, J.; Giri, S.; Munkarah, A.; et al. Folic acid tagged nanoceria as a novel therapeutic agent in ovarian cancer. BMC Cancer 2016, 16, 220. [CrossRef] [PubMed]

70. Kwon, H.J.; Cha, M.Y.; Kim, D.; Kim, D.K.; Soh, M.; Shin, K.; Hyeon, T.; Mook-Jung, I. Mitochondria-targeting ceria nanoparticles as antioxidants for Alzheimer's disease. ACS Nano 2016, 10, 2860-2870. [CrossRef] [PubMed]

71. Dowding, J.M.; Song, W.; Bossy, K.; Karakoti, A.; Kumar, A.; Kim, A.; Bossy, B.; Seal, S.; Ellisman, M.H.; Perkins, G.; et al. Cerium oxide nanoparticles protect against Aß-induced mitochondrial fragmentation and neuronal cell death. Cell Death Differ. 2014, 21, 1622-1632. [CrossRef] [PubMed]

72. Heer, C.D.; Davis, A.B.; Riffe, D.B.; Wagner, B.A.; Falls, K.C.; Allen, B.G.; Buettner, G.R.; Beardsley, R.A.; Riley, D.P.; Spitz, D.R. Superoxide dismutase mimetic GC4419 enhances the oxidation of pharmacological ascorbate and its anticancer effects in an $\mathrm{H}_{2} \mathrm{O}_{2}$-dependent manner. Antioxidants (Basel) 2018, 7, 18. [CrossRef] [PubMed]

(C) 2018 by the authors. Licensee MDPI, Basel, Switzerland. This article is an open access article distributed under the terms and conditions of the Creative Commons Attribution (CC BY) license (http://creativecommons.org/licenses/by/4.0/). 